\section{Evaluation of Caladium Cultivars for Sensitivity to Chilling}

\author{
Zhanao Deng ${ }^{1}$ and Brent K. Harbaugh
}

AdDitional INDEX words. Caladium $\times$ hortulanum, cold tolerance, resistance to chilling injury, cold-tolerance breeding

Summary. Caladium (Caladium $\times$ hortulanum) leaves can be injured at air temperatures below $15.5^{\circ} \mathrm{C}$. This chilling sensitivity restricts the geographical use of caladiums in the landscape, and leads to higher fuel costs in greenhouse production of pot plants because warmer conditions have to be maintained. This study was conducted to develop procedures to evaluate differences among caladium cultivars for chilling sensitivity and to identify cultivars that might be resistant to chilling injury. The effects of two chilling temperatures $\left(12.1\right.$ and $\left.7.2^{\circ} \mathrm{C}\right)$ and three durations ( 1,3 , and 5 days) on the severity of chilling injury were compared for three cultivars known to differ in their sensitivity to low temperatures. Exposure of detached mature leaves to $7.2{ }^{\circ} \mathrm{C}$ for 3 days allowed differentiation of cultivars' chilling sensitivity. Chilling injury appeared as dark necrotic patches at or near leaf tips and along margins, as early as 1 day after chilling. Chilling injury became more widespread over a 13-day period, and the best window for evaluating cultivar differences was 9 to 13 days after chilling. Significant differences in chilling sensitivity existed among 16 cultivars. Three cultivars, 'Florida Red Ruffles', 'Marie Moir', and 'Miss Muffet', were resistant to chilling injury. These cultivars could serve as parents for caladium cold-tolerance breeding, and this breeding effort could result in reduced chilling injury in greenhouse production of potted plants, or in new cultivars for regions where chilling occurs during the growing season.

$\mathrm{C}$ aladiums are tropical aroids grown in containers, hanging baskets, and landscapes for their bright, colorful leaves. Plant breeding in the last 150 years or so has resulted in a diversity of leaf shapes, colors, and color patterns in commercial caladium cultivars (Hayward, 1950; Wilfret, 1993a). Commercial caladium plants are produced by forcing tubers in containers. The majority $(>90 \%)$ of caladium tubers in the world market are produced (propagated) in central Florida (Bell et al., 1998). Being geophytes, the aboveground part of caladium plants is comprised of leaves. The ornamental value of caladium plants in containers or their performance in the landscape is determined, to a great extent, by the quantity, quality, and characteristics of their leaves.

University of Florida, IFAS, Environmental Horticulture Dept, Gulf Coast Research and Education Center, 14625 CR 672, Wimauma, FL 33598.

We thank Richard Kelly, Joyce Jones, Nancy West, and Gail Bowman for their excellent technical support. This research was supported by the Florida Agricultural Experiment Station and a grant from the Fred C. Gloeckner Foundation, Inc., and approved for publication.

${ }^{1}$ To whom reprint requests should be addressed. E-mail address: zdeng@ifas.ufl.edu
Originated in the New World tropics, caladiums are very sensitive to low temperatures. This low temperature sensitivity is expressed on growing (or sprouting) plants as well as on dormant tubers. Harbaugh (1990) reported that exposure to temperatures of 12.8 to $15.5^{\circ} \mathrm{C}$ for 4 to $6 \mathrm{~d}$ restricted the growth of potted caladium plants and caused necrosis on leaves and a considerable loss of market values. Marousky and Raulston (1973) showed that storage temperatures below 15.5 ${ }^{\circ} \mathrm{C}$ delayed or completely inhibited sprouting of stored tubers, and that tubers planted and kept at 10 or 15.5 ${ }^{\circ} \mathrm{C}$ failed to develop roots or leaves. Exposure of caladium tubers to $2^{\circ} \mathrm{C}$ for $7 \mathrm{~d}$ resulted in browning and dehydration of bud scales in the central buds; longer exposures caused damage to the lateral buds as well (Lavee et al., 1985). When 'Carolyn Whorton' tubers were exposed to temperatures below $5{ }^{\circ} \mathrm{C}$ for 1 to 3 weeks, they showed more active respiration and electrolyte leakage (Woodson and Raiford, 1985). Chilling-injured tubers produced much fewer daughter tubers (Lavee et al., 1985). These studies indicated that chilling injury could occur to caladium leaves or tubers at temperatures as high as $15.5^{\circ} \mathrm{C}$. Caladium's chilling sensitivity could potentially lead to problems (slow or uneven sprouting) and increases fuel costs in greenhouse production of potted plants, affecting plant performance negatively (necrosis on leaves) and restricting their use in the landscape.

Several other aroid species such as aglaonema (Aglaonema spp.) and spathiphyllum (Spathiphyllum spp.) are highly sensitive to chilling temperatures as well. Chilling injury occurred to 'Silver Queen' aglaonema at temperatures as high as $13^{\circ} \mathrm{C}$ (Chase et al., 1983). One-day exposure of spathiphyllum 'Clevelandii' to $10{ }^{\circ} \mathrm{C}$ resulted in necrotic patches along leaf margins (Marousky, 1980). Significant variation in chilling sensitivity was found among aglaonema species and cultivars (Chen et al., 2001; Hummel and Henny, 1986) and spathiphyllum cultivars (Chen et al., 2000). Several cultivars resistant to chilling injury were identified in these genera (Chen et al., 2000, 2001; Hummel and Henny, 1986). Authors of these studies indicated that breeding and selection could play an important role in improving chilling resistance in these foliage plants. Experimental procedures based on whole plants or detached leaves were developed for evaluation of chilling resistance in aglaonema and spathiphyllum (Chen et al., 1998, 2001; Qu et al., 2000).

Information about differences in chilling sensitivity among caladium cultivars was not available. Observation of field-grown caladium plants after natural-winter cold fronts at Bradenton, Fla., indicated potential to find such a difference in caladium (G.J. Wilfret, unpublished data). However, several factors, such as the sporadic nature of winter cold fronts and the

\begin{tabular}{llll}
\hline $\begin{array}{l}\text { Units } \\
\text { To convert U.S. to SI, } \\
\text { multiply by }\end{array}$ & U.S. unit & SI unit & $\begin{array}{l}\text { To convert SI to U.S., } \\
\text { multiply by }\end{array}$ \\
\hline 29.5735 & $\mathrm{fl} \mathrm{oz}$ & $\mathrm{mL}$ & 0.0338 \\
2.5400 & inch $(\mathrm{es})$ & $\mathrm{cm}$ & 0.3937 \\
0.5933 & $\mathrm{lb} / \mathrm{yard}^{3}$ & $\mathrm{~kg} \cdot \mathrm{m}^{-3}$ & 1.6856 \\
$\left({ }^{\circ} \mathrm{F}-32\right) \div 1.8$ & ${ }^{\circ} \mathrm{F}$ & ${ }^{\circ} \mathrm{C}$ & $\left(1.8 \times{ }^{\circ} \mathrm{C}\right)+32$
\end{tabular}


natural dieback of leaves, make it difficult to assess the chilling sensitivity or resistance levels of caladium cultivars in the field. The objectives of this study were to l) develop procedures, based on controlled-temperature treatments, to evaluate the chilling sensitivity of caladium leaf blades, and 2) identify chilling-resistant commercial cultivars for use in caladium cold-tolerance breeding, greenhouse production, and landscaping.

\section{Materials and methods}

Material. 'Brandywine', 'Candidum', 'Candidum Jr.', 'Carolyn Whorton', 'Florida Red Ruffles', Florida Sweetheart', 'Florida Sunrise', 'Frieda Hemple', 'Gingerland', 'Marie Moir', 'Miss Muffet', 'Pink Beauty', 'Red Flash', 'Red Frill', 'White Christmas', and 'White Queen' caladiums were used in this study. These cultivars comprised about $60 \%$ of the total acreage used for commercial tuber production in Florida in 1998 (Bell et al., 1998) and they provided a range of leafshapes, colors, and color patterns (Table 1). 'Florida Sweetheart' (Wilfret, 1991), 'Florida Sunrise' (Wilfret, 1993b), and 'Florida Red Ruffles' (G.J. Wilfret, unpublished release) were released within the last 15 years and have known parents. The origin of the rest of the cultivars is largely unknown, and they have been vegetatively propagated for 50 to 150 years.

Caladium plants were forced on 22 July 2004 from tubers [grade \#1 (1.5-2.5 inches in diameter)] that were cured and stored at $21{ }^{\circ} \mathrm{C}$ and $40 \%$ relative humidity (RH) for about 7 months. Plastic containers (azalea pots, 5 inches in diameter, $750-\mathrm{mL}$ volume) were filled with Vergro Container Mix A (Verlite Co., Tampa, Fla.). A controlled release fertilizer, Osmocote 15-9-12 (15N-3.9P-10K; Scotts Co., Marysville, Ohio), was added to the mix at $9 \mathrm{lb} /$ yard $^{3}$. Plants were grown in a shaded greenhouse with $40 \%$ light exclusion under a natural photoperiod at Bradenton, Fla. Temperatures in the greenhouse ranged from 24 to $37^{\circ} \mathrm{C}$.

Chilling treatment. Mature leaves were excised from pot plants (3-4 months old) near the petiole base with a clipper and placed immediately in plastic buckets filled with tap water $[\mathrm{pH}=7.3$, electrical conductivity $(\mathrm{EC})=0.28]$. The majority of the leaf petiole was submerged in the water. Leaves of each cultivar for each temperature/duration treatment were tied together below the petiole attachment with a piece of plastic tape and labeled accordingly. Bundles of leaves from different cultivars for the same treatment were placed in a plastic bucket filled with tap water pre-chilled to $21.1^{\circ} \mathrm{C}$. This bucket of leaves with the water was placed inside a growth chamber (series 101; Percival Scientific, Boone, Iowa) whose temperature was set and stabilized overnight before the chilling treatment. Leaves were kept in the growth chambers for 1 to $5 \mathrm{~d}$. Twelve hours of light at 50 to 100 umol $\cdot \mathrm{m}^{-2} \cdot \mathrm{s}^{-1}$ was provided daily with cool fluorescent tubes and incandescent light bulbs.

EVALUATION OF CHILLING INJURY. For Expt. 1, Expt. 2, and Expt. 3, the buckets of leaves were removed from the growth chambers and transferred to an evaluation room where each bundle of leaves was placed in a $500-\mathrm{mL}$ glass flask filled with tap water. The flasks with leaves were arranged on tables in a randomized complete-block fashion. The temperature, relative humidity, and light level in the evaluation room were maintained at $26.7 \pm 1{ }^{\circ} \mathrm{C}, 50 \%$ to $70 \%$, and 30 to $50 \mu \mathrm{mol} \cdot \mathrm{m}^{-2} \cdot \mathrm{s}^{-1}$ ( 24 h daily), respectively. The primary indicator of chilling injury used in this study was area of necrotic leaf tissue. The percentage of the total necrotic areas on each leaf blade was estimated by dividing the whole leaf blade into 10 sections and assessing the injured area in each section.

EXPT. 1: EFFECT OF LOW TEMPERATURES AND DURATIONS ON THE

Table 1. Variation among 16 caladium cultivars in sensitivity to chilling at $7.2{ }^{\circ} \mathrm{C}$ for $3 \mathrm{~d}$. Leaf injury evaluated $9 \mathrm{~d}$ after chilling $\left[\left(1.8 \times{ }^{\circ} \mathrm{C}\right)+32={ }^{\circ} \mathrm{F}\right]$.

\begin{tabular}{|c|c|c|c|c|}
\hline Cultivar & $\begin{array}{c}\text { Leaf } \\
\text { characteristics }\end{array}$ & $\begin{array}{c}\text { Leaf area } \\
\text { injured (\%) }\end{array}$ & $\begin{array}{l}\text { Leaf injury } \\
\text { score }\end{array}$ & Category \\
\hline Marie Moir & White fancy, green main vein, red spots & $9 \mathrm{e}^{\mathrm{z}}$ & $3.3 \mathrm{e}^{\mathrm{y}}$ & Resistant \\
\hline Florida Red Ruffles & Red lance, ruffled margin & 9 e & $3.5 \mathrm{e}$ & Resistant \\
\hline Miss Muffet & Lemon green, burgundy spots & $10 \mathrm{e}$ & $4.1 \mathrm{e}$ & Resistant \\
\hline Red Frill & Red lance & $18 \mathrm{de}$ & $5.4 \mathrm{~b}-\mathrm{e}$ & Sensitive \\
\hline Florida Sweetheart & Rose wide lance & $18 \mathrm{de}$ & $5.3 \mathrm{c}-\mathrm{e}$ & Sensitive \\
\hline White Queen & Fancy, deep red vein & 19 de & $5.3 \mathrm{c}-\mathrm{e}$ & Sensitive \\
\hline Candidum & White fancy, green main veins & $21 \mathrm{de}$ & $5.1 \mathrm{c}-\mathrm{e}$ & Sensitive \\
\hline Pink Beauty & Pink fancy & $22 \mathrm{de}$ & $5.2 \mathrm{c}-\mathrm{e}$ & Sensitive \\
\hline Brandywine & Red fancy & $25 \mathrm{c}-\mathrm{e}$ & $5.7 \mathrm{~b}-\mathrm{e}$ & Sensitive \\
\hline Candidum Jr. & White fancy, green main veins & $27 \mathrm{c}-\mathrm{e}$ & $5.6 \mathrm{~b}-\mathrm{e}$ & Sensitive \\
\hline Frieda Hemple & Red fancy & $33 \mathrm{~b}-\mathrm{d}$ & $5.9 \mathrm{~b}-\mathrm{d}$ & Sensitive \\
\hline Carolyn Whorton & Pink fancy, large blotches & $34 \mathrm{~b}-\mathrm{d}$ & $6.3 \mathrm{~b}-\mathrm{d}$ & Sensitive \\
\hline Red Flash & Red fancy, light pink spots & $38 \mathrm{~b}-\mathrm{d}$ & $6.2 \mathrm{~b}-\mathrm{d}$ & Sensitive \\
\hline White Christmas & White fancy, green main veins & $48 \mathrm{a}-\mathrm{c}$ & $7.7 \mathrm{ab}$ & Very sensitive \\
\hline Florida Sunrise & Multi-color fancy & $56 \mathrm{ab}$ & $7.5 \mathrm{a}-\mathrm{c}$ & Very sensitive \\
\hline Gingerland & Fancy leaf with red spots & $65 \mathrm{a}$ & $9.3 \mathrm{a}$ & Very sensitive \\
\hline $\operatorname{LSD}(P \leq 0.05)$ & & 21 & 2.4 & \\
\hline
\end{tabular}

${ }^{2}$ Percentage of leaf area injured was assessed $9 \mathrm{~d}$ after chilling and was transformed. Mean separation within column by SAS GLM procedure and LSD at $P \leq 0.05$. Numbers in the same column followed by the same letter are not significantly different.

yScores were made on a scale of 1 to $10: 1=$ no injury, bright and healthy as those of the control; $2=$ some discoloration or yellowing; $3=1 \%$ to $2 \% ; 4=3 \%$ to $5 \% ; 5=6 \%$ to $10 \% ; 6=11 \%$ to $20 \% ; 7=21 \%$ to $35 \% ; 8=36 \%$ to $55 \% ; 9=56 \%$ to $75 \%$; and $10=76 \%$ to $100 \%$ of the total leaf area injured. Mean separation within column by SAS GLM procedure and least significant difference (lsd) at $P \leq 0.05$. Numbers in the same column followed by the same letter are not significantly different. 
DEgReE OF CHILling INJURY. Three cultivars known to differ in chilling sensitivity, 'Florida Red Ruffles', 'Pink Beauty', and 'White Christmas', were used for this experiment. Mature leaves of each cultivar were prepared as described above, and then a $3 \times 3$ factorial experiment was conducted, with three temperatures $(21.1,12.2$, and $7.2^{\circ} \mathrm{C}$ ) and three durations ( 1,3 , and $5 \mathrm{~d}$ ). The experimental unit was three mature leaves in a bundle. All bundles of leaves for a specific temperature/duration were placed in one bucket. The $21.1{ }^{\circ} \mathrm{C}$ treatments were considered as the controls.

EXPT. 2: DEVELOPMENT OF CHILLING INJURY OVER TIME. Mature leaves of 'Florida Red Ruffles', 'Pink Beauty', and 'White Christmas' (in bundles of three leaves) were exposed to $7.2^{\circ} \mathrm{C}$ for $3 \mathrm{~d}$. The percentage of injured area on each leaf was assessed $3,5,7,9,11$, and $13 \mathrm{~d}$ after the chilling treatment. Leaves exposed to $21.1^{\circ} \mathrm{C}$ for $3 \mathrm{~d}$ were used as a control.

Expt. 3: Evaluation of 16 CULTIVARS FOR CHILLING SENSITIVITY. Thirty mature leaves per cultivar were excised from pot plants and randomly separated into 10 bundles of three leaves. Bundles of leaves from all 16 cultivars for one temperature treatment and one replicate were placed in a plastic bucket filled with tap water and exposed to $7.2^{\circ} \mathrm{C}$ for $3 \mathrm{~d}$ in a growth chamber. Bundles of leaves exposed to $21.1{ }^{\circ} \mathrm{C}$ in growth chambers for 3 $\mathrm{d}$ were used as controls. The severity of chilling injury was evaluated $9 \mathrm{~d}$ after treatment as percentage of the leaf area injured. In addition, the severity of chilling injury on each leaf was rated on a scale of 1 to $10: 1=$ no injury, bright and healthy as those of the control; $2=$ some discoloration or yellowing; $3=1 \%$ to $2 \% ; 4=3 \%$ to $5 \% ; 5=6 \%$ to $10 \% ; 6=11 \%$ to $20 \%$; $7=21 \%$ to $35 \% ; 8=36 \%$ to $55 \% ; 9=$ $56 \%$ to $75 \%$; and $10=76 \%$ to $100 \%$ of the total leaf area injured. Cultivars were categorized as chilling-resistant $(<10 \%$ of leaf area, and rating score $<5$ ), sensitive ( $10 \%$ to $35 \%$ of leaf area, and rating score 5 to 7 ), or very sensitive ( $>35 \%$ of leaf area injured, and rating score $>7$ ) based on their response to exposure to $7.2^{\circ} \mathrm{C}$ for $3 \mathrm{~d}$.

EXPERIMENT DESIGN AND STATISTICAL ANALYSIS. For all experiments, treatments were replicated five times. Temperatures were randomly assigned to growth chambers. Leaves of different cultivars or exposed to different chilling treatments were arranged in the evaluation room in a randomized complete-block fashion. Effects of cultivars on chilling injury were analyzed using the general linear model procedure of SAS (release 9.0 for Windows; SAS Institute, Cary, N.C.), and the cultivar differences were separated by the least significant difference (LSD) procedure at $P=0.05$. Before analysis of variance and mean separation, data transformation was performed for the percent leaf area injured (y) using the formula arcsine [square root $(\mathrm{y} / 100)]$.

\section{Results and discussion}

EFFECTS OF CHILLING TEMPERATURE AND DURATION ON LEAF INJURY. Exposure to $7.2{ }^{\circ} \mathrm{C}$ for as little as 1 d caused noticeable chilling injury on 'White Christmas' (19\% leaf area injured) and 'Pink Beauty' ( $8 \%$ area injured) (Fig. 1). As the exposure was extended to 3 and $5 \mathrm{~d}$, chilling injury became more widespread on their leaf blades. The percentage of 'White Christmas' leaf area injured increased to $48 \%$ and $65 \%$ after 3 and $5 \mathrm{~d}$ exposure, respectively. The same trend was observed on 'Pink Beauty' as well as 'Florida Red Ruffles' leaves when the duration of chilling was extended. The most severe injury (i.e., the highest percentage of leaf area damaged) for each cultivar occurred after exposure to $7.2^{\circ} \mathrm{C}$ for $5 \mathrm{~d}$. 'Florida Red Ruffles' and 'White Christmas' showed the least and the most severe injury, respectively, while 'Pink Beauty' was intermediate.

Exposure to $12.2^{\circ} \mathrm{C}$ for $1 \mathrm{~d}$ resulted in some injury (6\%) on 'White Christmas' leaf blades, but generally caused little damage to 'Florida Red Ruffles' and 'Pink Beauty' leaf blades (Fig. 1). As the chilling treatment was extended to 3 and $5 \mathrm{~d}$, larger areas were injured on 'White Christmas' and 'Pink Beauty' leaves, but still little on 'Florida Red Ruffles' leaves. With the $12.2^{\circ} \mathrm{C}$ chilling treatments, the trend among the three cultivars in chilling sensitivity was not as consistent as what was observed with the $7.2^{\circ} \mathrm{C}$ chilling treatment.

Generally no injury was observed on leaves exposed to $21.1{ }^{\circ} \mathrm{C}$; however, some discoloration or necrosis appeared on 'White Christmas' leaves after they had been exposed to $21.1^{\circ} \mathrm{C}$ for $5 \mathrm{~d}$. This indicates that $5 \mathrm{~d}$ exposure, at least in some cultivars, to growth chamber conditions with low levels of light ( 50 to $100 \mu \mathrm{mol} \cdot \mathrm{m}^{-2} \cdot \mathrm{s}^{-1}$ ) might complicate the evaluation of cultivar differences in chilling sensitivity. Taking this into consideration, it seems that exposure of mature leaves to 7.2 ${ }^{\circ} \mathrm{C}$ for $3 \mathrm{~d}$ would provide adequate chilling to reveal differences in chilling sensitivity in caladium.

DEVELOPMENT OF CHILLING INJURY SYMPTOMS OVER TIME. Chilling injury in caladium was characterized by dark necrotic patches on leaf blades. Injuries frequently occurred at and near the leaf tips and along the leaf margin, and were surrounded by a narrow yel-

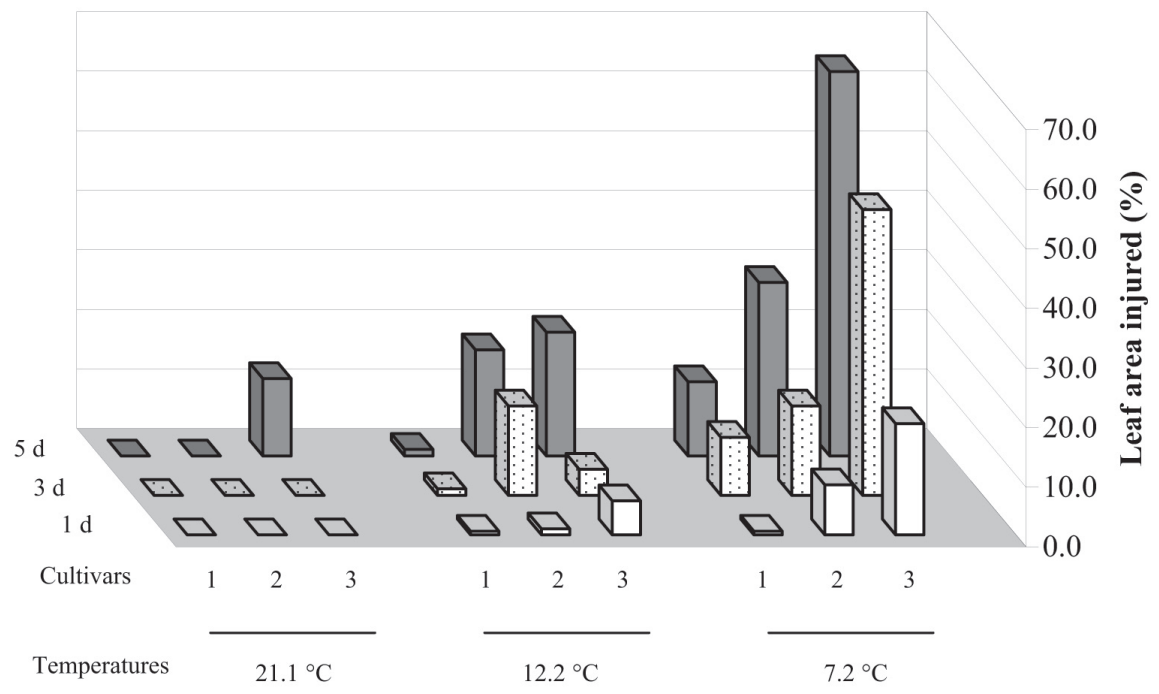

Fig. 1. Effects of three temperatures $\left(21.1,12.2\right.$, and $\left.7.2^{\circ} \mathrm{C}\right)$ and three exposure durations $(1,3$, and $5 \mathrm{~d})$ on the percentage of leaf area injured $\left[\left(1.8 \times{ }^{\circ} \mathrm{C}\right)+32\right.$ $\left.={ }^{\circ} \mathrm{F}\right]$; 1 = 'Florida Red Ruffles'; 2 = 'Pink Beauty'; and 3 = 'White Christmas' caladium. 
lowing strip. When temperature was low or duration was long, injuries occurred between midribs and near the leaf petiole attachment area as well. These symptoms appeared as early as 1 $\mathrm{d}$ after exposure to $7.2^{\circ} \mathrm{C}$ for $3 \mathrm{~d}$ and increased over time. Fig. 2 shows the increase in injury in 'White Christmas', 'Pink Beauty', and 'Florida Red Ruffles' leaves over a 13-d period. Change was most obvious in 'White Christmas': injured leaf area increased from $23 \%$ to 58.7\%. In 'Florida Red Ruffles', chilling injury occurred in much smaller areas on leaf blades and the increase in injury over time was small, from $2 \%$ to $9 \%$. The increase in injured leaf area over time in 'Pink Beauty' (9\% to $25 \%$ ) was intermediate between that of 'White Christmas' and 'Florida Red Ruffles'. The appropriate time frame to evaluate cultivar differences in chilling injury appears to be 9 to $13 \mathrm{~d}$ after a chilling treatment.

VARIATION IN CHILLING RESISTANCE AMONG CULTIVARS. In the control treatment, no cultivar showed chilling injury, while in the chilling treatment, significant differences in injury among these cultivars were observed (Table 1; Fig. 3). 'White Christmas', 'Florida Sunrise', and 'Gingerland' had 48\% to $65 \%$ of their leaf areas injured by the chilling treatment, thus forming the most sensitive group. 'Brandywine', 'Candidum', 'Candidum Jr.', 'Red Frill', 'Red Flash', and 'Florida Sweetheart' had $18 \%$ to $38 \%$ of their leaf areas injured. 'Florida Red Ruffles', 'Marie Moir', and 'Miss Muffet' had less than $10 \%$ of their leaf blade areas injured by the chilling treatment, and thus were categorized as the chillingresistant group.

When these cultivars were evaluated on a scale of 1 to 10 , very sensitive cultivars ('White Christmas', 'Florida Sunrise', and 'Gingerland') had a score of 7.5 to 9.3 ; sensitive cultivars ('Florida Sweetheart', 'White Queen', 'Candidum', 'Pink Beauty', 'Brandywine', 'Candidum Jr.', 'Frieda Hemple', 'Carolyn Whorton', and 'Red Flash') scored 5.1 to 6.3; and the resistant cultivars had a score of 3.3 to 4.1 .

Like several other tropical ornamental aroids, such as aglaonema and spathiphyllum, caladiums are sensitive to chilling temperatures. To avoid chilling injury, higher temperatures must be maintained in greenhouses for production of potted caladium plants and

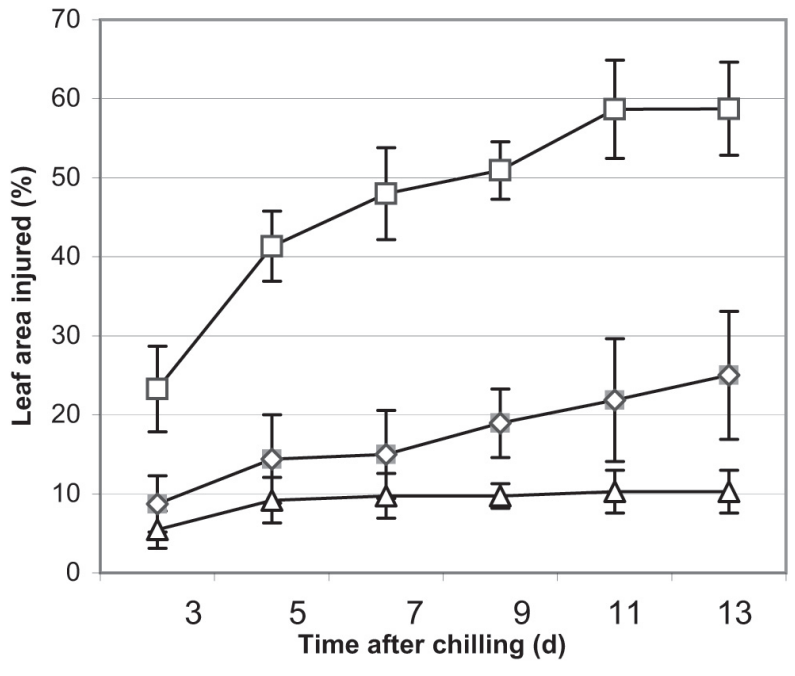

Fig. 2. Leaf injury of three caladium cultivars $(\square=$ 'White Christmas', $\downarrow=$ 'Pink Beauty', and $\Delta=$ 'Florida Red Ruffles') over a period of $13 \mathrm{~d}$ after they were exposed to $7.2{ }^{\circ} \mathrm{C}$ for $3 \mathrm{~d}\left[\left(1.8 \times{ }^{\circ} \mathrm{C}\right)+32={ }^{\circ} \mathrm{F}\right]$.

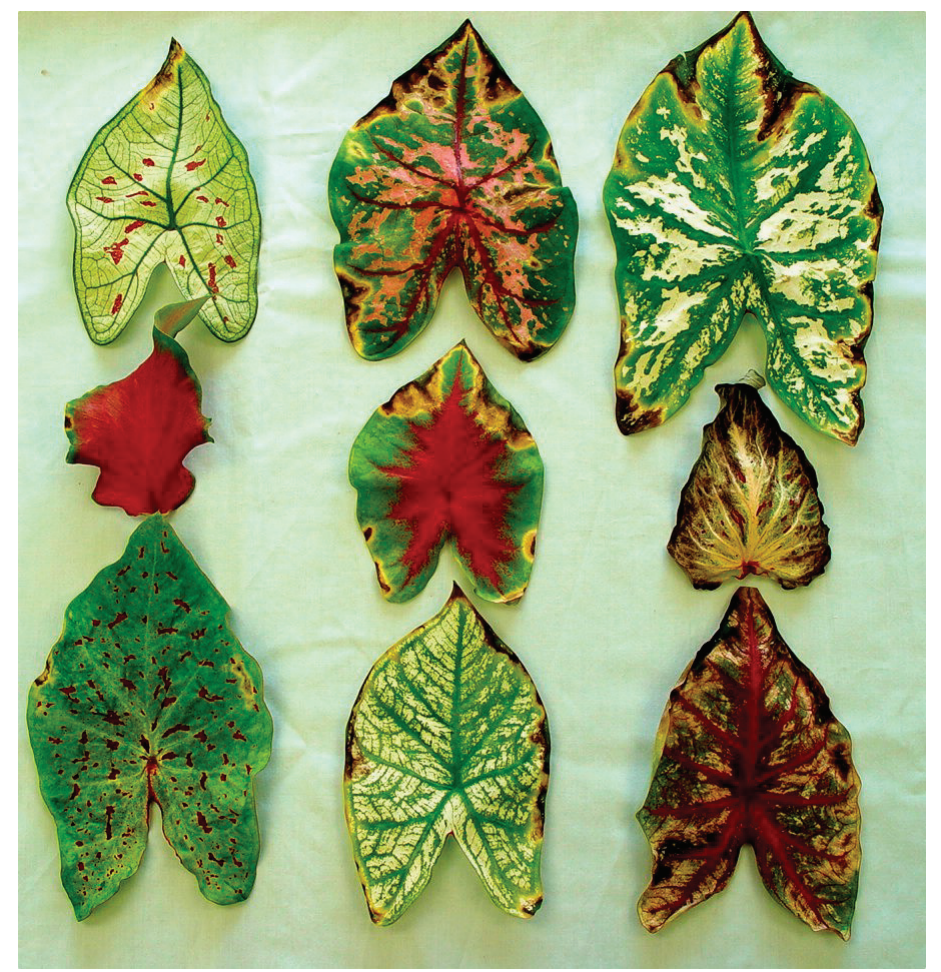

Fig. 3. Chilling injury on the leaf blades of nine cultivars $8 \mathrm{~d}$ after exposure to $7.2{ }^{\circ} \mathrm{C}$ for $3 \mathrm{~d}\left[\left(1.8 \times{ }^{\circ} \mathrm{C}\right)+32={ }^{\circ} \mathrm{F}\right]$. Left column (chilling resistant) from top to bottom: 'Marie Moir', 'Florida Red Ruffles', and 'Miss Muffet'; middle column (chilling sensitive) from top to bottom: 'Carolyn Whorton', 'Frieda Hemple', and 'Candidum Jr.'; and right column (very sensitive) from top to bottom: 'White Christmas', 'Gingerland', and 'Florida Sunrise'.

in transport vehicles, which results in higher fuel costs. The geographical use of caladium plants in the landscape is also restricted by their chilling sensitivity. Development of chilling-resistant cultivars has been one of the objectives in caladium breeding, but this effort has been hindered by lack of chilling-resistant breeding parents. 'Miss Muffet' and 'Marie Moir', as well as 'Florida Red Ruffles', seem to be much less sensitive to chilling temperatures, and they may be valuable as chilling-resistant parents in breeding for caladium 
cold tolerance. The chilling resistance evaluation procedure developed in this study is based on response of detached leaves to chilling temperatures, and could be applied readily to large-scale progeny screening for cold tolerance. This procedure allows for much better control of chilling and evaluation conditions and was more consistent than whole-pot plant-based or fieldgrown plant-based procedures (Deng and Harbaugh, unpublished).

'Florida Red Ruffles' was developed from a cross between 'Candidum' and 'Red Frill' and was released as a cold-tolerant cultivar (G.J. Wilfret, unpublished release). It is interesting to note that 'Florida Red Ruffles' had less leaf injury than its parents and was more resistant to chilling. This seems to indicate the potential for transgressive chilling-resistant segregants in caladium breeding populations. It remains to be confirmed if this is a common phenomenon in caladium. If transgressive inheritance does occur in the chilling injury resistance trait, it should improve our ability to develop caladium cultivars that are more tolerant than those currently available.

\section{Literature cited}

Bell, M.L., G.J. Wilfret, and D.A. Devoll. 1998. Survey of caladium tuber producers for acreage of cultivars grown. Proc. Florida State Hort. Soc. 111:822-838.

Chase, A.R., R.T. Poole, and L.S. Osborne. 1983. Aglaonema. Florida Nurseryman $30: 25-28$.

Chen, J., R.W. Henley, R.J. Henny, R.D. Caldwell, and C.A. Robinson. 1998. A simple leaf assay method for evaluating Aglaonema sensitivity to chilling temperatures. Proc. Florida State Hort. Soc. 111:43-46.

Chen, J., R.W. Henley, C.A. Robinson, R.D. Caldwell, and Y. Huang. 2000. Response of spathiphyllum cultivars to chilling temperatures. Proc. Florida State Hort. Soc. 113:165-169.

Chen, J., R.W. Henley, R.J. Henny, R.D. Caldwell, and C.A. Robinson. 2001. Aglaonema cultivars differ in resistance to chilling temperatures. J. Environ. Hort. 19:198-202.

Harbaugh, B.K. 1990. Transit duration $\times$ temperature and fertilization of prefinished caladiums affect subsequent growth. HortScience 25:554-555.

Hayward, W. 1950. Fancy-leaved caladiums. Plant Life 6:131-142.

Hummel, R.L. and R.J. Henny. 1986. Variation in sensitivity to chilling injury within the genus Aglaonema. HortScience 21:291-293.
Lavee, A., A. Borochou, and A.H. Halevy. 1985. Effects of growing and storage temperatures on growth and tuber yield of caladium. Scientia Hort. 26:175-182.

Marousky, F.J. 1980. Chilling injury in Dracaena sanderana and Spathiphyllum 'Clevelandii'. HortScience 15:197-198.

Marousky, F.J. and J.C. Raulston. 1973. Influence of temperature and duration of curing, storage, shipping, and forcing periods on caladium growth. Proc. Florida State Hort. Soc. 86:363-368.

Qu, L., J. Chen, R.J. Henny, C.A. Robinson, R.D. Caldwell, and Y. Huang. 2000. Response of Spathiphyllum cultivars to chilling temperatures. Proc. Florida State Hort. Soc. 113:165-169.

Wilfret, G.J. 1991. Florida Sweetheart-A rose lance caladium for landscape and containers. Univ. Florida Agr. Expt. Sta. Circ. S-380.

Wilfret, G. J. 1993a. Caladium, p. 239-247. In: A. DeHertogh and M. LeNard (eds.). The physiology of flower bulbs. Elsevier, Amsterdam.

Wilfret, G.J. 1993b. 'Florida Sunrise' caladium. HortScience 28:237-238.

Woodson, W.R. and T.J. Raiford. 1985. Response of caladium tubers to low, nonfreezing temperatures. HortScience 20:929-931. 